\title{
NEWYYPBK HOOL
}

digitalcommons.nyls.edu

Faculty Scholarship

Articles \& Chapters

2012

\section{Justice's Beautiful Face: Bob Sadoff and the Redemptive Promise of Therapeutic Jurisprudence}

Michael L. Perlin

New York Law School, michael.perlin@nyls.edu

Follow this and additional works at: https://digitalcommons.nyls.edu/fac_articles_chapters

\section{Recommended Citation}

Journal of Psychiatry and Law, Vol. 40, Issue 2 (Summer 2012), pp. 265-292

This Article is brought to you for free and open access by the Faculty Scholarship at DigitalCommons@NYLS. It has been accepted for inclusion in Articles \& Chapters by an authorized administrator of DigitalCommons@NYLS. 


\section{"Justice's beautiful face": Bob Sadoff and the redemptive promise of therapeutic jurisprudence}

BY MICHAEL L. PERLIN, J.D.

Therapeutic jurisprudence (TJ) provides a framework for psycholegal analysis that has had no difficulty in attracting adherents within the law and a broad range of health-oriented disciplines. Although psychiatry has proven perhaps predictably less willing to embrace TJ, the work of Robert L. Sadoff, M.D. provides a heartening exception. Dr. Sadoff's career stands for many enlightening principles-not least of which is the redemptive promise of $T J$.

KEY WORDS: Forensic psychiatry, legal education, professional ethics, therapeutic jurisprudence.

I first met Bob Sadoff on a snowy day in my then-office in Trenton over 40 years ago.' Since then, we have worked together-and continue to do so-professionally in every imaginable way, ${ }^{2}$ and we have shared life cycle events from

AUTHORS' NOTE: For additional information about this article, please contact Professor Michael L. Perlin, New York Law School, 185 West Broadway, New York, NY 10013. E-Mail: michael.perlin@nyls.edu. The author wishes to thank Alison Lynch for her helpful research assistance. 
bar and bat mitzvahs to weddings to baseball games. ${ }^{3}$ This article, though, will focus only on one aspect of our relationship, and one that has not been the focus of much prior attention: the mutuality of purpose that we both have found in the way that therapeutic jurisprudence (TJ) values synergistically inform and support the relationship between forensic expert and counsel in the litigation and pre-trial processes. I began this article as I did simply to reinforce the connectivity in our careers, and to underscore how my relationship with Bob is among the few most important of my professional (and personal) life (lives). And part of that relationship is Bob's commitment-both as a scholar and as an expert witness ${ }^{4}$ - to the values of care, the avoidance of harm, and the well-being of those who come in contact with the forensic system, commitments that resonate in the TJ literature.

In this article, I will first briefly explain the meaning of therapeutic jurisprudence. Next, I will look at Bob's writing that has been explicitly about $\mathrm{TJ}$, to be followed by (a) a consideration of Bob's other writing that has clearly been inspired by his adherence to TJ principles (although those are not necessarily specified), and (b) a consideration of some of the reported litigated cases in which Bob has testified in which his testimony reflects TJ values. I will conclude with some thoughts about Bob's contributions in this area, coupled with some speculations as to why so few forensic psychiatrists ever write from this perspective. ${ }^{5}$

\section{The meaning of $\mathbf{T J}$}

One of the most important legal theoretical developments of the past two decades has been the creation and dynamic growth of therapeutic jurisprudence (TJ). ${ }^{6}$ Initially employed in cases involving individuals with mental disabilities, but subsequently expanded far beyond that narrow area, therapeutic jurisprudence presents a new model for assessing 
the impact of case law and legislation, recognizing that, as a therapeutic agent, the law that can have therapeutic or antitherapeutic consequences. ${ }^{7}$ The ultimate aim of therapeutic jurisprudence is to determine whether legal rules, procedures, and lawyer roles can or should be reshaped to enhance their therapeutic potential while not subordinating due process principles. ${ }^{8}$ There is an inherent tension in this inquiry, but David Wexler clearly identifies how it must be resolved: "the law's use of "mental health information to improve therapeutic functioning [cannot] impinge upon justice concerns." As I have written elsewhere, "An inquiry into therapeutic outcomes does not mean that therapeutic concerns 'trump' civil rights and civil liberties." 10

Therapeutic jurisprudence "asks us to look at law as it actually impacts people's lives" "ll and focuses on the law's influence on emotional life and psychological well-being. ${ }^{12}$ It suggests that "law should value psychological health, should strive to avoid imposing anti-therapeutic consequences whenever possible, and when consistent with other values served by law should attempt to bring about healing and wellness." 13 By way of example, therapeutic jurisprudence "aims to offer social science evidence that limits the use of the incompetency label by narrowly defining its use and minimizing its psychological and social disadvantage. ${ }^{\prime 14}$

In recent years, scholars have considered a vast range of topics through a therapeutic jurisprudence lens, including, but not limited to, all aspects of mental disability law, domestic relations law, criminal law and procedure, employment law, gay rights law, and tort law. ${ }^{15}$ As Ian Freckelton has noted, "it is a tool for gaining a new and distinctive perspective utilizing socio-psychological insights into the law and its applications." 16 It is also part of a growing comprehensive movement in the law towards establishing more humane and psychologically optimal ways of handling legal issues collaboratively, creatively, and 
respectfully. ${ }^{17}$ These alternative approaches optimize the psychological well-being of individuals, relationships, and communities dealing with a legal matter, and acknowledge concerns beyond strict legal rights, duties, and obligations. In its aim to use the law to empower individuals, enhance rights, and promote well-being, therapeutic jurisprudence has been described as "...a sea-change in ethical thinking about the role of law.... movement towards a more distinctly relational approach to the practice of law... which emphasises psychological wellness over adversarial triumphalism."18 That is, therapeutic jurisprudence supports an ethic of care. ${ }^{19}$

One of the central principles of therapeutic jurisprudence is a commitment to dignity. Ronner describes the "three Vs": voice, validation and voluntariness, ${ }^{20}$ arguing:

What "the three Vs" commend is pretty basic: litigants must have a sense of voice or a chance to tell their story to a decision maker. If that litigant feels that the tribunal has genuinely listened to, heard, and taken seriously the litigant's story, the litigant feels a sense of validation. When litigants emerge from a legal proceeding with a sense of voice and validation, they are more at peace with the outcome. Voice and validation create a sense of voluntary participation, one in which the litigant experiences the proceeding as less coercive. Specifically, the feeling on the part of litigants that they voluntarily partook in the very process that engendered the end result or the very judicial pronunciation that affects their own lives can initiate healing and bring about improved behavior in the future. In general, human beings prosper when they feel that they are making, or at least participating in, their own decisions. ${ }^{21}$

Bob's writing-Bob's professional life-seeks to elevate the importance of these "three Vs" in the entire forensic/legal process.

\section{Bob Sadoff's writings on therapeutic jurisprudence}

Over 30 years ago, in a chapter in a book on violence, murder, and aggression, Bob and I said this about the connec- 
tion between law and mental health: "The intersection of law and mental health stands at a significant focal point in the development of human behavior, at a point where motives, intents, and drives can and must be examined in the contexts of rights, obligations, duties and the social order." ${ }^{22}$ Certainly, these early views were consonant with what came to be known as therapeutic jurisprudence. In 1993, I put together a symposium on therapeutic jurisprudence at New York Law School. I believe it is the first such symposium ever presented at a law school in this nation. Of course, David Wexler and Bruce Winick came and presented, ${ }^{23}$ as did other prominent law professors, ${ }^{24}$ law practitioners, ${ }^{25}$ and forensic psychologists. ${ }^{26}$ But Bob Sadoff also came to offer the perspective of the forensic psychiatrist. ${ }^{27}$ This is one of the very few articles ever by a forensic psychiatrist directly about this topic; interestingly, the others also appear mostly in nonmedical journals. ${ }^{28}$

When I reread this article as part of my preparation for this article, I was struck both by Bob's prescience and how, immediately, he grasped the most significant tension in TJ. In the second paragraph of this piece, he asks two back-toback questions:

Is the decision made in keeping with the patient's best interest? Does the patient have autonomy in this particular case or is the patient the product of the paternalistic mental health system $?^{29}$

And, in the final paragraph of this article:

The notion [of TJ] is sound as long as it is applied consistently and pursued by the courts where mentally ill clients, defendants or plaintiffs, are involved. However, the rights of patients and the needs of the law are not always in concert with therapeutic principles regarding the best medical interest of the individuals concerned. ${ }^{30}$

Here, Bob sets up one of the issues at the heart of the TJ inquiry (and also, not coincidentally, perhaps the root of the basic criticism that TJ was "paternalistic," perhaps auguring 
a return to a therapeutic state) ${ }^{31}$ : Can a legal system be "therapeutic" and still support and privilege autonomy? The debate on this question is still with us 18 years later. ${ }^{32}$

Bob's piece was also extraordinarily prescient as to the ultimate impact of $\mathrm{TJ}$. Although $\mathrm{TJ}$ began as solely an interpretive tool to answer questions of mental disability law, he saw its potential impact on such areas as domestic relations, personal injury, substantive criminal law, correctional law, and sex offender law. ${ }^{33}$ In a recent article reviewing 2 decades of TJ scholarship, Wexler specifically earmarked "the advance of therapeutic jurisprudence from its starting point in mental health law to its present involvement in the entire legal spectrum. ${ }^{34}$ Bob intuitively and immediately saw these broad applications not from his academic perspective, I don't think, but from his work as an expert witness in all of these areas of the law. And certainly, time has borne out his insights. ${ }^{35}$

Bob's other writings from an (unspoken)

TJ

perspective
One of the basic tenets of $\mathrm{TJ}$ is the avoidance of harm: "Interactions with the justice system necessarily have an impact on an individual's psychological or emotional wellbeing and that the system should be designed to minimize emotional or psychological harm and maximize benefit to the extent possible consistent with other system objectives." ${ }^{36} \mathrm{TJ}$ also calls for a careful consideration of the ethical roles of all participants in the forensic mental health system. In an article I wrote with Professor Keri Gould over a decade ago about the impact of $\mathrm{TJ}$ on clinical teaching, we noted that $\mathrm{TJ}$ requires an "examination of and eventual tinkering with the roles and behavior of judges and attorneys so that those persons may perform in a fashion that meshes with professional ethics and yet is therapeutically beneficial." ${ }^{37}$ TJ also mandates "increased attention to race, ethnicity, and culturally competent practice in the lawyer-client relationship." ${ }^{38}$ Further, TJ serves as a bulwark against bias, offering "an avenue to transform the way the criminal justice system deals with 
mentally ill offenders from a system rooted in stereotypical bias against the mentally ill to a system that preserves due process principles, while also focusing on healing." ${ }^{39} \mathrm{TJ}$ also demands that principles of informed consent be "authentically" honored.$^{40}$ Also, TJ considers the contours of forensic testimony and of the relationship between factfinders and expert witnesses. ${ }^{41}$ A consideration of Bob's other writings reveals that these issues are core to his scholarship and professional persona.

In his most recent book, Ethical Issues in Forensic Psychiatry: Minimizing Harm, ${ }^{42}$ Bob begins by noting that his book is about "the inherent harm that may be caused in the practice of forensic psychiatry," 43 and that the forensic psychiatrist must consciously seek to minimize harm in the conduct of examinations and evaluations. ${ }^{44} \mathrm{He}$ emphasizes how the forensic process can be harmful to the examinee (by including certain information in the report, ${ }^{45}$ by using certain words in the report, ${ }^{46}$ by giving opinions not based on scientific evidence) $)^{47}$ as well as to the examiner, ${ }^{48}$ and lists multiple substantive situations (e.g., examination of children; examination of individuals claiming sexual harassment; examination of persons with mental retardation) in which harm can come to the examinee. ${ }^{49} \mathrm{He}$ extensively discusses the need for cultural knowledge and how cultural differences must be accounted for in forensic evaluations. ${ }^{50}$ Stressing that the judicial system is not a therapeutic one, ${ }^{51}$ he nonetheless argues (persuasively) that the forensic examination has therapeutic potential, ${ }^{52}$ and concludes that the forensic expert-once in the courtroom-must become a teacher. ${ }^{53}$

In other writings, Bob warns about the pitfalls of personal bias on the part of the forensic expert, stressing that forensic psychiatrists with negative feelings about certain defendants (based on race or ethnicity) should not be involved in such a person's case.$^{54}$ Elsewhere, in writing about repressed memory treatments, he warns about the need to obtain 
informed consent before embarking on experimental treatments (e.g., hypnosis, sodium amytal) as part of the forensic evaluation." 55 In 1983, in writing about the right to refuse treatment (at a time when mainstream psychiatric opposition to that right was virulent), ${ }^{56}$ he endorsed a "cooperative model to help resolve disputes [related to] ethical conflicts." ${ }^{57}$ In discussing the vexing problem of the role of the forensic psychiatrist in death penalty competency determinations, he cautions-in total consonance with TJ principles-that "the psychiatrist must know the extent and limitations of his or her expertise and maintain ethical standards while making a significant contribution to the court." 58 And again, and again, he focuses on the ethical issues that permeate the entire forensic process-with regard to personal bias, ${ }^{59}$ agency relationships, ${ }^{60}$ and the entire civil commitment process. ${ }^{61}$

Not insignificantly, practicing lawyers and law professors have embraced Bob's insights. Professor Daniel Shuman, in a commentary on Troxel $v$. Granville, ${ }^{62}$ a grandparent visitation case, has noted, citing Bob's TJ piece: "For many mental health professionals, therapeutic jurisprudence represents an overdue attention to the unintended mental and emotional harm that the law often produces and its squandered therapeutic potential." ${ }^{63}$ Janet Abisch, in an article endorsing a meditational approach to civil commitment representation, has drawn on Bob's work on ethical dilemmas and the dilemma of power imbalances in involuntary hospital settings: "As hospital administrators control virtually all aspects of the system-access, time, conditions of confinement, communications-a power imbalance is created, making it almost impossible for lawyers to deal with their clients, to confront witnesses, or to develop proofs without abandoning their best interests stance for a more adversarial, confrontational one." ${ }^{64}$ Elaine Dahl, in an article discussing the Montana Supreme Court's decision in $\operatorname{In} \operatorname{Re}$ K.G.F., articulating an expansive role of 
lawyers in civil commitment cases ${ }^{65}$ has drawn on the same piece as did Abisch: "Scholars have frequently decried the lack of guidance for counsel in involuntary commitment proceedings, noting that cases, statutes, and codes of professional responsibility provide little or no assistance." ${ }^{66}$

In short, Bob's thoughts about therapeutic jurisprudenceboth when he references TJ and where he does not-have had a significant impact on the legal academy. ${ }^{67}$

In case law I turn my attention now to the topic of case law. Bob has evaluated over 10,000 defendants in criminal cases, ${ }^{68}$ a truly astounding number. And, equally astonishing, the decisions in at least 212 cases in which he testified have been published. ${ }^{69}$ What can we learn from these?

There are limitations to the scope of this inquiry, of course. An expert witness in a criminal or personal injury or disability case will not announce to the court that he or she has approached a case from a therapeutic jurisprudence perspective. ${ }^{70}$ But I believe that a careful reading of the case law may illuminate the extent to which TJ values-even sub silentio - have had an impact on the witness's testimony.

By way of example, in State $v$. Sheppard, ${ }^{71}$ a criminal prosecution involving a sexual attack on a 10 -year-old child, Bob testified that he believed the victim had the capacity to testify truthfully, but-in testimony that reflects the essence of $\mathrm{TJ}$ principles ${ }^{72}$ - he concluded that avoidance of an incourt appearance through the use of video equipment would improve the accuracy of her testimony. These were the reasons he offered:

An adult witness, testifying in court, surrounded by the usual court atmosphere, aware of a black-robed judge, a jury, attorneys, members of the public, uniformed attendants, a flag, and religious overtones, is more likely to testify truthfully. The opposite is true of a child, particularly when the setting involves a relative accused by her of sexual abuse. She becomes fearful, guilty, anxious, and trau- 
matized. In most cases, she will have been exposed to both pleasant and abusive associations with the accused. As a consequence, she has ambivalent feelings. Anger against the relative is opposed by feelings of care, not only for him but also for other family members who may be harmed by a conviction. There is guilt as well as satisfaction in the prospect of sending the abuser to prison. These mixed feelings, accompanied by the fear, guilt, and anxiety, mitigate the truth, producing inaccurate testimony. The video arrangement, because it avoids courtroom stress, relieves these feelings, thereby improving the accuracy of the testimony. ${ }^{73}$

This is a question that has been the topic of significant scholarly commentary in subsequent years, ${ }^{74}$ but I have not been able to find an earlier suggestion in the case law in which an expert witness took this position.

Questions of power also play a part in Bob's testimony. In State $v$. Nelson, ${ }^{75}$ a death penalty case involving a transsexual defendant, Bob made it clear that he was, again, in court as an educator, not a partisan, ${ }^{76}$ and that he "did not consider himself a member of the prosecution's team." 77 Although, ironically, the conviction in this case was reversed in significant part because of the prosecutor's juxtaposing that testimony with the testimony of the defense witness (who considered himself a member of the "defense team") ${ }^{78}$ Bob's testimony, standing alone, certainly is a reflection of core $\mathrm{TJ}$ values.

Bob is comfortable testifying that he does not have enough information to form an expert opinion to a reasonable medical certainty. ${ }^{79}$ In one case-dealing with the question of whether a defendant was competent to be executed ${ }^{80}$ he testified that he had part of the information he needed, but not all of it:

Based on my limited and abbreviated one hour examination of Antuan Bronshtein plus review of the records noted, I can state, within reasonable medical certainty, that $\mathrm{Mr}$. Bronshtein appears to have an intellectual ability to understand that he is being put to death for a particular reason, i.e., the conviction for murder of Alexander Guttman [sic]. I am not certain about his emotional 
appreciation of the conditions in which he finds himself and his ability to work effectively and rationally with counsel with respect to his current situation....

Thus, my opinion at this time is deferred until a further examination, where I may probe more deeply into Mr. Bronshtein's emotional condition and his reasons for seeking the death penalty as quickly as possible. ${ }^{81}$

TJ rejects the notion of expert omniscience. ${ }^{82}$ Bob's testimony in cases such as these reflects a strict adherence to this position.

Bob has also offered creative solutions to seemingly intractable problems in the criminal court process. ${ }^{83}$ In United States $v$. Rodriguez,${ }^{84}$ in an incompetency hearing in a counterfeiting conspiracy case, Bob concluded that the defendant's misunderstandings were "more educational issues than they [were] mental health issues and [could] be restored through educational rehabilitation prior to trial." (Id.), and that [the defendant's] "ability to work with counsel" constituted "an issue that needs to be addressed," though with "proper education and training, it was likely...that... Rodriguez would achieve [this] ability" (Id.). ${ }^{85}$ Following this testimony, the parties agreed to enroll Rodriguez in a competency restoration process that included the sort of training Bob had recommended. ${ }^{86}$ Bob's recommendations in the Rodriguez case certainly reflect the sort of non-adversarial approach to criminal justice urged by some TJ commentators. ${ }^{87}$

In short, Bob doesn't simply "talk the talk." As reflected in a sampling of reported cases, he truly "walks the walk" as well.

\section{Conclusion}

So what conclusions can we draw from all this? It seems to me that there are a few overarching points worthy of some consideration: 
1. Bob immediately "got" the significance of therapeutic jurisprudence, as an interpretative tool, as a filter, and as a structure for the forensic legal process.

2. He intuitively knew that its ultimate value would transcend the world of mental disability law, and that it would have major impacts on virtually every other area of substantive and procedural law.

3. He incorporated his insights not solely in his $\mathrm{TJ}$-specific writings and his general law-and-psychiatry writings, but into his testimony as well.

4. Bob is, truly, nearly alone as a psychiatrist in his embrace of TJ.

I need to add a few words on this final point, because it is so troubling on so many levels. As I indicated above, ${ }^{88}$ there is only a handful of articles by psychiatrists that are explicitly $\mathrm{TJ}$ in orientation. ${ }^{89}$ Not only that: the literature seems to assume that psychiatrists will not "take" to TJ. Writing about potential TJ adopters, David Wexler notes, "Another relevant community is that of social workers, criminologists, psychologists, and the like" ${ }^{90}$; Philip Gould and Patricia Murrell have characterized TJ as a "catalyst for interdisciplinary outreach, synthesizing the work of lawyers and judges with that of criminologists, sociologists, psychologists, philosophers, educators, and law professors." 1 The absence of psychiatrists from these lists is, on one hand, startling, but on the other, realistic.

There is some irony here, of course. From the onset of the patients' rights movement, organized psychiatry has complained long and loud about being "belegaled." ${ }^{2}$ And soon thereafter, David Wexler, making specific reference to this position, noted that "the topic of the 'belegalment' of various professionals seems highly suitable for a therapeutic jurisprudence analysis." ${ }^{93}$ Yet, psychiatrists have largely been utterly silent about $\mathrm{TJ}$ and its potentially redemptive powers to lessen some of the tensions between law and psychiatry. ${ }^{94}$ 
But Bob Sadoff is the major (practically, the lone) exception. As with so many other aspects of the forensic system and the law/psychiatry overlap, Bob "got it" early on, and has stayed with it ever since. Although the words "therapeutic jurisprudence" do not appear in his most recent book, ${ }^{95}$ the book's focus on power, on avoidance of harm, and on "the prevention of exploitation" 96 of vulnerable litigants by skilled experts is a perfect embodiment of TJ values. It is more than sad that so few of Bob's fellow professionals have taken up the same banner. My hope in writing this article is that some will be convinced to do so.

I conclude by explaining the title of this paper. One of the highlights of Bob Dylan's 1983 album Infidels is the powerful song, $I$ and $I .{ }^{97}$ At the end of the third verse, Dylan sings: "Took a stranger to teach me, to look into justice's beautiful face/And to see an eye for an eye and a tooth for a tooth." The song may be, as Paul Williams suggests, a reflection of a change in Dylan's persona since his previous albums (released during his so-called Born Again period), as it is profoundly influenced by the Old Testament. ${ }^{98}$ Whether or not that is so, this couplet- vacillating between justice and vengeance-reflects the theme of the song. And the phrase "justice's beautiful face" is key to an understanding of the song, as justice must be a foundational principle of religion.

So is "justice" the foundational principle of therapeutic jurisprudence. David Wexler has explicitly linked TJ to the concept of justice as a basic human need. ${ }^{99}$ Bruce Winick has argued that TJ must be "consistent with principles of justice. ${ }^{100}$ Others have concluded that $\mathrm{TJ}$ "regards the law as a social force that... will serve to promote justice," remind us that $\mathrm{TJ}$ cannot be employed to subordinate due process or "other justice values;" 102 TJ "raises our attention to this and encourages us to see whether the law can be made or applied in a more therapeutic way so long as other values such as justice can be fully respected." 103 In a recent 
article, I suggested that TJ was the "school of jurisprudence that can optimally redeem" mental disability law. ${ }^{104}$ Bob's work can help attain this redemption.

Like Bob Dylan, Bob Sadoff understands this, embraces this, and lives this. We are all extraordinarily lucky that he is in our lives.

Notes 1 I discuss this in Michael L. Perlin, "May He Stay Forever Young": Robert Sadoff and the History of Mental Health Law, 33 J. AMER. ACAD. Psychiatry \& L. 236 (2005).

2 These include, but are certainly not limited to:

- Bob has been a witness in many cases that I have litigated (I discuss some of these in Perlin, supra note 1; see also, 4 Michael $L$. Perlin, Mental Disability Law: Civil and Criminal, \& 8A-6.3, at 88 (2d ed. 2002), discussing State v. Miller, Indictment No. 1869-71 (N.J. Mercer Cty. Ct. 1974), and Michael L. Perlin, Psychiatric Testimony in a Criminal Law Setting, 3 Bull. AM. ACAD. Psychiatry \& L. 143, 1249 n. 20 (1975)(same) (Criminal Law Setting), and has been the inspiration for others (see Perlin, supra note 1, at 236, discussing Dixon v. Cahill, Docket No. L.30977/y-71 P.W. (N.J. Super. Ct., Law Div. 1973), final order reprinted in 5 Perlin, supra, \$14-7, at 119-21 (2d ed. 2002).

- We have taught together and presented on panels together (from 1979 to 1984, we taught together as members of the Faculty for Continuing Education in the Program in Psychiatry at the Institute of the Pennsylvania Hospital (Philadelphia, PA); we have shared the podium innumerable times at meetings of the American Academy of Psychiatry and Law, the American Association of Law Schools, the American Psychiatric Association, the International Academy of Law and Mental Health, and other cross-professional organizations).

- We have made teaching tapes together (the sample direct and cross-examination that I include in my Treatise (see 1 Perlin, supra, $\S 2 \mathrm{C}-4.9$, at $338-53$ (2d ed. 1998)) is based on the Roland Rodney tape that Bob and I created in the late 1970s pursuant to a National Institute of Mental Health training project in conjunction with the Center for Studies in Social-Legal Psychiatry at the University of Pennsylvania Medical School, which Bob then directed); 
Bob also made a series of teaching tapes for me and with me ("The Case of Sharon Stevens"; "The Case of Darren Daniels") that I used in classes at New York Law School from 1990-2004.

- We have coauthored articles (e.g., Michael L. Perlin \& Robert L. Sadoff, Ethical Issues in the Representation of Individuals in the Commitment Process, 45 Law \& Contemp. ProBs. 161 (1982) (ethical issues); Michael L. Perlin \& Robert L. Sadoff, The Adversary System, in Violence: Perspectives on Murder and AgGression 394 (Irwin L. Kutash, Samuel B. Kutash, Louis B. Schlesinger eds., 1978)).

- Lhave written chapters in books he has edited (e.g., Michael L. Perlin, Recent Developments in Mental Health Law, in Psychiatric Clinics of North America 539 (Robert Sadoff ed. 1983); Michael L. Perlin, Competency to Stand Trial, in Crime and Mental Illness: A Guide to Courtroom Practice 23 (Robert Sadoff \& Frank Dattillio eds., 2008)).

- He has served on monitoring committees of cases I have litigated (see Perlin, supra note 1, at 243 (discussing the monitoring committee in Doe v. Klein, Docket No. L-12088-74 P.W. (N.J. Super. Ct., Law Div. 1977), reported in 1 Ment. Dis. L. Rep. 425 (1977) (Greystone Park Psychiatric Hospital case, Morris Plains, NJ)).

- I present regularly in his Practical Applications Seminar series at the University of Pennsylvania Medical School (most recently, e.g., Promoting Social Change in Asia and the Pacific: The Need for a Disability Rights Tribunal to Give Life to the Convention on the Rights of Persons with Disabilities (Dec. 6, 2011)).

- $\quad$ have given a lecture in a series honoring Bob (International Human Rights and Mental Health Law, at the Robert L. Sadoff Lecture sponsored by the Section on Medicine, Ethics, and the Law; Philadelphia College of Physicians (April 2009)), and one in a series honoring his parents (The Right to Refuse Treatment, Adequacy of Counsel, and Evolving Changes in the Regulation of Pharmacy, annual Max and Rose Sadoff Lecture, University of Minnesota School of Pharmacy (April, 1996)).

- Bob gave me my national start by inviting me to present at an American Academy of Psychiatry and Law meeting in 1975 (see Criminal Law Setting, supra).

- He has written about me in his books (see Robert L. SAdoff, ETHICAl Issues in Forensic Psychiatry: Minimizing Harm 73 (2011)).

- $\quad$ have written about him in my articles (see, e.g., Michael L. Perlin "They Keep It All Hid": The Ghettoization of Mental Disability 
Law and Its Implications for Legal Education, 54 ST. Lous U. L. J. 857, 871 (2010) (Perlin, Ghettoization); Michael L. Perlin, A Law of Healing, 68 U. Cin. L. Rev. 407, 417 (2000) (Perlin, Healing)).

- Lhave written introductory forwards to two of his books (see Michael L. Perlin, Foreword: New Directions in the Legal Regulation of the Mental Health Professions, in ROBERT SIMON \& ROBERT L. Sadoff, Psychiatric Malpractice: Cases and Comments For Clinicians IX (1992); Michael L. Perlin, Foreword, in Robert L. Sadoff, Legal Issues in the Care of Psychiatric Patients: A Guide for the Mental Health Professional XI (1982)).

- I've even written an article in an earlier Festschrift honoring Bob (see supra note 1).

I have attended the weddings of his son David and his daughter Debbie, and he has attended the bar mitzvah of my son Alex and the bat mitzvah of my daughter Julie (I couldn't find the invitation lists to cite. Readers will have to take my word on this). We have gone to major league baseball and NBA basketball games together (The most notable of which being the 1979 Phils 23-22 victory over the Cubs at Wrigley Field; see http://www.bloggingbaseball.com $/ 2006 / 05 / 17 /$ major-league-baseballs-wildest-gamesphillies-23-chicago-cubs-22-at-wrigley-field/. I must note that we were at an American Psychiatric Association conference and Bob, inexplicably, left before it was over, mentioning that he had to present another paper. I stayed til the end). I still haven't had the opportunity to attend a Bob Dylan concert with Bob, but I am still working on that. The fact that they are both Minnesota boys adds a certain je ne sais quoi to that possibility.

I cannot speak as to how he conducts his therapeutic sessions although I do know that his expressed concerns about power imbalances in forensic relationships speaks, even if sub silentio, to therapeutic jurisprudence-the focus of this paper-as well. See e.g., Minimizing HaRm, supra note 2, at 101: "Expert witnesses have a certain amount of power that must not be abused or misused to the detriment of others' freedom or their lives" (emphasis added).

The contrast here to forensic psychologists-who have widely adopted $\mathrm{TJ}$ as a a scholarly topic and working approach-is startling and puzzling. For a sampling of the robust literature by psychologists about therapeutic jurisprudence and the impact that therapeutic jurisprudence might have on the practice of psychology, see e.g., Astrid Birgden, Therapeutic Jurisprudence 
and "Good Lives": A Rehabilitation Framework for Corrections, 37 Austl. Psychologist 180 (2002); Ian Freckelton \& David List, The Transformation of Regulation of Psychologists by Therapeutic Jurisprudence, 11 PsychIATRY, PsychoL. \& L. 296 (2004); Mark A. Small, Legal Psychology and Therapeutic Jurisprudence, 37 ST. Louis U. L.J. 675 (1993); Richard L. Wiener, Social Analytic Jurisprudence and Tort Law: Social Cognition Goes to Court, 37 ST. Louis U. L.J. 503 (1993); Joel Haycock, Speaking Truth to Power: Rights, Therapeutic Jurisprudence, and Massachusetts Mental Health Law, 20 New Eng. J. ON Crim. \& Civ. Confinement 301 (1994); Kathy Faulkner Yates, Therapeutic Issues Associated with Confidentiality and Informed Consent in Forensic Evaluations, 20 New ENG. J. ON CRIM. \& Civ. Confinement 345 (1994); Sharon G. Portwood et al., Social Science Contributions to The Study of Domestic Violence within the Law School Curriculum, 47 LoY. L. Rev. 137 (2001).

See, e.g., David B. Wexler, Therapeutic Jurisprudence: The Law as a Therapeutic Agent (1990); David B. Wexler \& Bruce J. Winick, Law in a Therapeutic Key: Recent Developments in Therapeutic Jurisprudence (1996); Bruce .J. Winick, Civil Commitment: A Therapeutic Jurisprudence Model (2005); David B. Wexler, Two Decades of Therapeutic Jurisprudence, 24 TOURo L. Rev. 17 (2008); 1 PerliN, supra note $2, \S 2 \mathrm{D}-3$, at $534-41$. Wexler first used the term in a paper he presented to the National Institute of Mental Health in 1987. See David B. Wexler, Putting Mental Health into Mental Health Law: Therapeutic Jurisprudence, 16 L. \& HUM. BEHAv. 27, 27, 32-33 (1992).

See Michael L. Perlin, "His Brain Has Been Mismanaged with Great Skill": How Will Jurors Respond to Neuroimaging Testimony in Insanity Defense Cases?, 42 AKRON L. REv. 885, $912(2009)$.

Michael L. Perlin, "You Have Discussed Lepers and Crooks": Sanism in Clinical Teaching, 9 CliniCAL L. Rev., 683-729 (2003); Michael L. Perlin, “And My Best Friend, My Doctor, Won't Even Say What It Is I've Got": The Role and Significance of Counsel in Right to Refuse Treatment Cases, 42 SAN DiEgo L. REv. 735 (2005); Michael L. Perlin, "Everybody Is Making Love/Or Else Expecting Rain": Considering the Sexual Autonomy Rights of Persons Institutionalized Because of Mental Disability in Forensic Hospitals and in Asia, 83 U. WASH. L. REv. 481 (2008). 
David B. Wexler, Therapeutic Jurisprudence and Changing Concepts of Legal Scholarship, 11 BeHAv. SCI. \& L. 17, 21 (1993).

Perlin, Healing, supra note 2, at 412; Michael L. Perlin, "Where the Winds Hit Heavy on the Borderline": Mental Disability Law, Theory and Practice, Us and Them, 31 Loyola L.A. L. Rev. 775, 782 (1998).

Bruce J. Winick, Forward: Therapeutic Jurisprudence Perspectives on Dealing With Victims of Crime, 33 Nova L. REv. 535,535 (2009).

David B. Wexler, Practicing Therapeutic Jurisprudence: Psychological Soft Spots and Strategies, in Daniel P. STOLle, David B. Wexler \& Bruce J. Winick, Practicing Therapeutic Jurisprudence: Law as a Helping Profession 45 (Stolle et al. eds., 2000).

Bruce Winick, A Therapeutic Jurisprudence Model for Civil Commitment, in Involuntary Detention and Therapeutic Jurisprudence: International Perspective on Civil Commitment, 23, 26 (Kate Diesfeld \& Ian Freckelton eds., 2003).

Claire B. Steinberger, Persistence and Change in the life of the Law: Can Therapeutic Jurisprudence Make A Difference? 27 LAw \& Psychol. Rev. 55, 65 (2003).

Michael L. Perlin, "Things Have Changed": Looking at Noninstitutional Mental Disability Law Through the Sanism Filter, 46 N.Y.L. SCH. L. REv. 535 (2002-03). As I note below, Bob predicted this development in 1990 and 1993. See infra text accompanying note 33 \& note 34 .

Ian Freckelton, Therapeutic Jurisprudence Misunderstood and Misrepresented: The Price and Risks of Influence, 30 T. JEFFERSON L. REV. 575, 582 (2008).

Susan Daicoff, The Role of Therapeutic Jurisprudence Within The Comprehensive Law Movement, in STOLLE et al. supra note 12, at 365.

Warren Brookbanks, Therapeutic Jurisprudence: Conceiving an Ethical Framework, 8 J.L. \& MED. 328, 329-330 (2001).

See, e.g., Bruce J. Winick \& David B. Wexler, The Use of Therapeutic Jurisprudence in Law School Clinical Education: Transforming the Criminal Law Clinic, 13 Clinical L. Rev. 605, 605-607 (2006); David B. Wexler, Not Such a Party Pooper: An Attempt to Accommodate (Many of) Professor Quinn's Concerns 
about Therapeutic Jurisprudence Criminal Defense Lawyering, 48 B.C. L. REv. 597, 599 (2007); Brookbanks, supra note 18; Gregory Baker, Do You Hear the Knocking at the Door? A "Therapeutic" Approach to Enriching Clinical Legal Education Comes Calling, 28 WhitTier L. Rev. 379, 385 (2006).

Amy D. Ronner, The Learned-Helpless Lawyer: Clinical Legal Education and Therapeutic Jurisprudence as Antidotes to Bartleby Syndrome, 24 Touro L. REv. 601, 627 (2008).

Amy D. Ronner, Songs of Validation, Voice, and Voluntary Participation: Therapeutic Jurisprudence, Miranda and Juveniles, 71 U. Cin. L. Rev. 89, 94-95 (2002); See generally, Амy D. RONNER, LAW, LITERATURE AND THERAPEUTIC JURISPRUDENCE (2010).

Adversary System, supra note 2, at 394.

Bruce Winick, Psychotropic Medication in the Criminal Trial Process: The Constitutional and Therapeutic Implications of Riggins v. Nevada, 10 N.Y.L. Sch. J. Hum. RTs. 637 (1993); David B. Wexler, New Directions in Therapeutic Jurisprudence: Breaking the Bounds of Mental Health Law Scholarship, 10 N.Y.L. ScH. J. Hum. RTs. 759, 776 (1993).

Daniel W. Shuman, Making the World a Better Place Through Tort Law?: Through the Therapeutic Looking Glass, 10 N.Y.L. ScH. J. Hum. RTs. 739, 758 (1993); Keri A. Gould, Turning Rat and Doing Time for Uncharged, Dismissed, or Acquitted Crimes: Do the Federal Sentencing Guidelines Promote Respect for the Law?, 10 N.Y.L. Sch. J. HuM. RTs. 835, 868-69 (1993).

Deborah A. Dorfman, Through a Therapeutic Jurisprudence Filter: Fear and Pretextuality in Mental Disability Law, 10 N.Y.L. SCH. J. HUM. RTs. 805, 816-19 (1993).

Fred Cohen \& Joel A. Dvoskin, Therapeutic Jurisprudence and Corrections: A Glimpse, 10 N.Y.L. SCH. J. Hum. RTs. 777 (1993) (Dvoskin is a forensic psychologist; Cohen a lawyer/professor); Murray Levine, A Therapeutic Jurisprudence Analysis of Mandated Reporting of Child Maltreatment by Psychotherapists, 10 N.Y.L SCH. J. Hum. RTS . 711 (1993).

Robert L. Sadoff, Therapeutic Jurisprudence: A View From a Forensic Psychiatrist, 10 N.Y.L. SCH. J. Hum. RTs. 825 (1993). The significance of his presence was subsequently noted in Christopher Slobogin, Therapeutic Jurisprudence: Five Dilemmas to Ponder. 1 Psychol. Pub. POL'y \& L. 193, 193 (1995). 
See, e.g., Richard Barnum and Thomas Grisso, Competence to Stand Trial in Juvenile Court in Massachusetts: Issues of Therapeutic Jurisprudence, 20 NEW ENG. J. ON CRIM. \& CIV. CONFINEMENT 321 (1994); Bill Glaser, Therapeutic Jurisprudence: An Ethical Paradigm for Therapists in Sex Offender Treatment Programs, 4 W. CRiminology Rev. 143 (2003); Douglas Mossman, Veterans Affairs Disability Compensation: A Case Study in Countertherapeutic Jurisprudence, 24 BULL. AM. ACAD. J. PSYCHIATRY \& L. 27 (1996). TJ values are also at the heart of Psychiatric Ethics and the Rights of Persons with Mental DisABILITIES IN THE COMMUNITY (2008), a book I coauthored with a forensic psychiatrist (Harold Bursztajn), a law professor (Kris Gledhill), and a lawyer-psychologist (Eva Szeli).

Sadoff, supra note 27 , at 825 .

Id. at 833 .

Valmaine Toki, Domestic Violence and Women: Can a Therapeutic Jurisprudence Approach Assist?, 78 REV. JUR. U.P.R. 61, 69 (2009); see also, Susan Stefan \& Bruce Winick, A Dialogue on Mental Health Courts, 11 Psychol. PUB. PoL'y \& L. 507, 524 (2005) (article is written in dialogue form; what follows is a comment by Prof. Stefan): "The courtroom is no place for a therapeutic alliance to be forged." Compare Perlin, Healing, supra note 11, at 412: "Therapeutic jurisprudence does not, cannot and must not be simply an elaborate academic justification for, in Nicholas Kittrie's famous phrase, 'a return to the therapeutic state" (see generally, Nicholas N. Kittrie, The Right to BE Different: Deviance and Enforced Therapy (1971)).

On this tension, see e.g., Bruce J. Winick, A Therapeutic Jurisprudence Approach to Dealing with Coercion in the Mental Health System, 15 Psychiatry, Psychology \& L. 25 (2008); Winsor C. Schmidt, Law and Aging: Mental Health Theory Approach 121, in THEORIES ON LAW AND AgeING: THE Jurisprudence of Elder LAW (Israel Doron ed., 2009); Dale Dewhurst, Analyzing the Normative Nature of Therapeutic Jurisprudence (Nov. 2, 2011) available at http://auspace .athabascau.ca/handle/2149/3122); Astrid Birgden, Therapeutic Jurisprudence and Offender Rights: A Normative Stance is Required, 78 Rev. Jur. U.P.R. 43 (2009).

Sadoff, supra note 27, at 827-33. See also, Robert L. Sadoff, When Is Law Therapeutic?, 9 CONTEMP. PsychIATRY 245, 246 (1990), discussing how "a focus solely on civil and criminal aspects of 
mental disability law is too narrow for therapeutic jurisprudence," Wexler, supra note 23, at 759.

David Wexler, Two Decades of Therapeutic Jurisprudence, 24 Touro L. Rev. 17, 17 (2008), and see Id. at 26: "Law professors incorporated therapeutic jurisprudence into class and into their writing, and saw applications not only in mental health law but in criminal law, tort law, and family law." See generally, David Wexler, Some Thoughts and Observations on the Teaching of Therapeutic Jurisprudence, 35 REV. DER. P.R. 273 (1996) (discussing how $\mathrm{TJ}$ branched out into other substantive areas of law).

See e.g., Leonore M.J. Simon, A Therapeutic Jurisprudence Approach to the Legal Processing of Domestic Violence Cases, I Psychol., Pub. Pol'y \& L. 43 (1995); Dennis P. Saccuzzo, How Should the Police Respond to Domestic Violence? A Therapeutic Jurisprudence Analysis of Mandatory Arrest, 39 SANTA Clara L. Rev. 765 (1999); David Wexler, Relapse Prevention Planning Principles for Criminal Law Practice, 5 Psychol., PuB. POL'y \& L. 1028 (1999); Robert Schopp \& David Wexler, Shooting Yourself in the Foot with Due Care: Psychotherapists and Crystallized Standards of Tort Liability, 17 J. PsychiATry \& L. 163 (1989); Astrid Birgden \& Frank Vincent, Maximising Therapeutic Effects in Treating Sexual Offenders in an Australian Correctional System, 18 Behav. SCI. \& L. 479 (2000); Astrid Birgden \& Michael L. Perlin, "Where the Home in the Valley Meets the Damp Dirty Prison": A Human Rights Perspective on Therapeutic Jurisprudence and the Role of Forensic Psychologists in Correctional Settings, 14 Aggression \& Violent BeHAV. 256 (2009); Jeffrey A. Klotz et al., Cognitive Restructuring Through Law: A Therapeutic Jurisprudence Approach to Sex Offenders and the Plea Process, 15 U. Puget Sound L. Rev. 579 (1992); Ida Dickie, Ethical Dilemmas, Forensic Psychology, and Therapeutic Jurisprudence, 30 T. JEFFERSON L. REV. 455 (2008).

Paul Holland, Lawyering and Learning in Problem-Solving Courts, 34 W ASH. U. J.L. \& POL'Y 185, 192 (2010).

Keri K. Gould \& Michael L. Perlin, "Johnny's in the Basement/Mixing Up His Medicine": Therapeutic Jurisprudence and Clinical Teaching, 24 SeattLe U. L. Rev. 339, 348 (2000).

Carolyn Copps Hartley \& Carrie J. Petrucci, Practicing Culturally Competent Therapeutic Jurisprudence: A Collaboration Between Social Work and Law, 14 WASH. U. J.L. \& POL'y 133, 135 (2004). 
Julie E. Grachek, The Insanity Defense in the Twenty-First Century: How Recent United States Supreme Court Case Law Can Improve the System, 81 IND. L. J. 1479, 1497 (2006). See also, Michael King, Restorative Justice, Therapeutic Jurisprudence and the Rise of Emotionally Intelligent Justice, 32 MELB. U. L. REV. 1096,1112 (2008) (on the need for TJ to take on an international perspective).

\section{Bruce J. Winick, The Right to Refuse Mental health} Treatment 341 (1997).

Perlin, Healing, supra note 2, at 417.

See supra note 2.

Id. at $\mathrm{xxx}$.

Id. at 70 .

Id. at 82 .

Id. at 88 .

Id. at 188 .

Id. at 183.

Id. at 77 .

Id. at 10-12, citing, inter alia. J. Richard Ciccone \& Colleen Clements, Forensic Psychiatry and Ethics-The Voyage Continues, 29 J. AM. ACAD. Psychiatry \& L. 174 (2001), and James W. Hicks, Ethnicity, Race and Forensic Psychiatry-Are We Color Blind? 32 J. Am. ACAD. Psychiatry \& L. 21 (2004).

Id. at 3.

Id. at 72 .

Id. at 186.

Robert L. Sadoff, The Practice of Forensic Psychiatry: Perils, Problems, and Pitfalls, 26 J. AM. ACAD. Psychiatry \& L. 305, 309 (1998). He addresses the other side of the same coin as well, cautioning forensic witnesses who, when examining an individual with a "strong religious, or other feeling similar to [her own], may not maintain the objective viewpoint that is necessary for effective forensic work." Id. 
Robert L. Sadoff, Child Abuse and Repressed Memory Testimony, 1 QuinniPIaC Health L.J. 79, 85 (1996), as discussed in Kathleen A. Biesterveld, False Memories and the Public Policy Debate: Toward a Heightened Standard of Care for Psychotherapy, 2002 WIS. L. Rev. 169, 207 (2002). See also, Joel Jay Finer, Therapists' Liability to the Falsely Accused for Inducing Illusory Memories of Childhood Sexual Abuse-Current Remedies and a Proposed Statute, 11 J.L. \& HEALTH 45, 55, 83 (1996-97) (discussing Sadoff, supra, at 85-86)

See e.g., Paul S. Appelbaum \& Thomas G. Gutheil, "Rotting With Their Rights On": Constitutional Theory and Clinical Reality in Drug Refusal by Psychiatric Patients, 7 Bull. AM. ACAD. Psychiatry \& L. 306 (1979); Darold A. Treffert, Dying with Their Rights On, 130 AM. J. Psychiatry 1041 (1973).

Robert L. Sadoff, Patient Rights Versus Patient Needs: Who Decides? 44 J. Clin. Psychiatry 27, 32 (1983). His testimony in recent court cases reflects this same attitude. See Commonwealth v. Watson, 952 A. 2d 541, 550 (Pa. 2008) ("Moreover, at the hearing on the defendant's competency, this Court determined, based on the testimony, that the defendant was not a danger to himself or others and therefore, could not be involuntarily medicated in an attempt to render him competent" (see testimony of Dr. Robert Sadoff, 10/18/04 N.T. at 14-39)).

Robert L. Sadoff, The Role of the Psychiatrist in Capital Punishment, 1 J. Forens. Psychiatry 73, 79 (1990).

Robert L. Sadoff, Practical Ethical Problems of the Forensic Psychiatrist in Dealing with Attorneys, 12 BULL. AM. ACAD. PSYCHIATRY \& L. 243, 245-46 (1984).

$I d$. at 249 (discussing here the issue of what he characterizes as "therapeutic zeal").

Ethical Issues, supra note 2 (discussing, inter alia, role conflicts, process conflicts and value conflicts that affect both the lawyer and the expert witness in the civil commitment process). David Wexler has graciously characterized this article as "classic" on the question of the importance of TJ skills in the civil commitment process. See David Wexler, Lawyer-Assistance-Program Attorneys and the Practice of Therapeutic Jurisprudence, 47 COURT REV. 64, 66 n. 19 (2011). 
Daniel W. Shuman, Troxel v. Granville and the Boundaries of Therapeutic Jurisprudence, 41 FAM. CT. REV. 67, 69 (2003).

Janet B. Abisch, Mediational Lawyering in the Civil Commitment Context, 1 Psych. Pub. Pol. \& L. 120, 131 (1995), citing Ethical Issues, supra note 2, at 131.

29 P. 3d 485 (Mont. 2001). See generally, Michael L. Perlin, "I Might Need a Good Lawyer, Could Be Your Funeral, My Trial": A Global Perspective on the Right to Counsel in Civil Commitment Cases, and Its Implications for Clinical Legal Education, 28 WASH. U. J. L. \& SoC=L POL=Y 241, 246-49 (2008).

Elaine M. Dahl, Taking Liberties: Analysis of In Re Mental Health of K.G.F., 64 MonT. L. REv. 295, 299 (2003), citing Ethical Issues, supra note 2 , at 162-63.

Other scholars have carefully considered Bob's views on a variety of other topics relevant to TJ inquiries. See e.g., Joanmarie Ilaria Davoli, Reconsidering the Consequences of an Insanity Acquittal, 31 New Eng. J. ON Crim. \& Civ. Confinement 3, xxx (2005) (incarceration of persons with mental illness); Joshua E. Kastenberg, A Three-Dimensional Model for the Use of Expert Psychiatric and Psychological Evidence in False Confession Defenses Before the Trier of Fact, 26 SEATTLE U. L. REV. 783, 805 (2003) (false confessions, citing ROBERT L. SADOFF, ForENSIC Psychiatry: A Practical Guide for LaWyers and Psychiatrists 76 (1975)); Jennie Lusk, Modern New Mexican Neonaticide: Tranquilizing with This Jewel/The Torments of Confusion, 11 TEX. J. Women \& L. 93, 101 (2001) (neonaticide); Christine Ann Gardner, Postpartum Depression Defense: Are Mothers Getting Away with Murder?, 24 NEw ENG. L. Rev. 953, 961 n. 68 \& 962 n. 75(1990) (same); Susan Stefan, Silencing the Different Voice: Competence, Feminist Theory and Law, 47 U. MIAMI L. Rev. 763, 776(1993) (individualistic aspects of competency, citing Robert $\mathrm{L}$. Sadoff, Medical-Legal Issues, in Comprehensive Review of Geriatric Psychiatry 637, 639 (Joel Sodavoy et al. eds., 1991); Lynn Akre, Struggling with Indeterminacy: A Call for Interdisciplinary Colloboration in Redefining the "Best Interest of the Child" Standard, 75 MARQ. L. REV. 628 (1992) (best interests of children in divorce proceedings, citing Robert L. Sadoff \& Stephen Billick, The Legal Rights and Difficulties of Children in Separation and Divorce, in CHILDREN OF SEPARATION AND DIVORCE 4, 4 (Irving R. Stuart \& Lawrence E. Abt eds., 1981)); Phyllis Coleman \& Ronald A. Shellow, Restricting Medical 
Licenses Based on Illness Is Wrong-Reporting Makes It Worse, 9 J.L. \& Health 273, 282 n. 35 (1994) (licensure issues related to physician health impairment, citing Robert L. Sadoff and Julie B. Sadoff, The Impaired Health Professional Legal and Ethical Issues, in Psychiatric-Legal Decision Making by the Mental Health Practitioner: The Clinician as Defacto Magistrate 259 (Harvey Bluestone et al. eds., 1994)).

See Minimizing HaRM, supra note 2, at 103.

WESTLAW search (January 25, 2012) in ALLCASES database for "Robert +2 Sadoff" or "Dr. Sadoff." In case some cases involved other Dr. Sadoffs, I refined the search by adding "\% Robert." That eliminated eight of the 220 first identified. This cohort includes civil as well as criminal cases.

Of the 19 published cases that contain the words "therapeutic jurisprudence," almost all cite articles with those words in the title. One case discusses (and rejects) overtly TJ arguments made by appellate counsel (see In re Alfred H.H., 910 N.E.2d 74 (Ill. 2009)); one approvingly cites legislative hearings related to adoption of court rules (see Amendment to the Rules of Juvenile Procedure, Fla. R. Juv. P. 8.350, 804 So.2d 1206 (Fla. 2001); one cites a court drafting committee report (see In re Report of Family Court Steering Committee, 794 So.2d 518 (Fla. 2001), and one cites legislative language (see Lawson v. State, 969 So.2d 222 (Fla. 2007)).

484 A. 2d 1330 (N.J. Super. Law Div. 1984).

The case was decided several years before the first appearance of $\mathrm{TJ}$ in the literature. See supra note 6.

Sheppard, 484 A. $2 \mathrm{~d}$ at 1332.

See e.g., Terry Maroney, Emotional Regulation and Judicial Behavior, 99 CAL. L. REv. 1485, 1532 (2011); CHILdREN AS Victims, Witnesses and Offenders: Psychological Science AND THE Law (Bette L. Bottoms, Cynthia J. Najdowski, \& Gail S. Goodman eds., 2009).

803 A. 2d 1 (N.J. 2002).

See Minimizing HaRM, supra note 2, at 186, discussed supra text accompanying note 53 .

Nelson, 803 A. 2d at 27. Compare Commonwealth v. Henry, 706 A.2d 313, 328 (Pa. 1997) ("After evaluating Henry, however, Dr. 
Sadoff informed counsel that Henry was not insane within the meaning of the M'Naghten standard at the time he killed Clery." Bob had been retained by defense counsel.)

Id. at 28 , characterizing prosecutor's statements as "clearly improper."

See e.g., Thomer v. Allstate Insurance Co., 790 F. Supp. 360, 365 (E.D. Pa. 2011) (case involving allegation of bad faith handling of insurance claim).

See e.g., Panetti v. Quarterman, 551 U.S. 930; see generally, Michael L. Perlin, "Good and Bad, I Defined These Terms, Quite Clear No Doubt Somehow": Neuroimaging and Competency to be Executed after Panetti, 28 BeHAV. SCI. \& L. 621 (2010).

Commonwealth v. Bronshtein, 729 A.2d 1102, 1103-04 (1999) (Sadoff report).

See LeRoy L. Kondo, The Tangled Web-Complexities, Fallacies and Misconceptions Regarding the Decision to Release Treated Sexual Offenders from Civil Commitment to Society, 23 N. ILL. U. L. Rev. 195, 215 (2003), discussing, in this context, Robert M. Wettstein, A Psychiatric Perspective on Washington's Sexually Violent Predators Statute, 4 U. Puget Sound L. Rev. 597, 632 (1992).

On this issue, see e.g., David B. Wexler, Rehabilitating Lawyers: Principles of Therapeutic Jurisprudence for Criminal Law Practice (2008); David B. Wexler, A Tripartite Framework for Incorporating Therapeutic Jurisprudence in Criminal Law, Research, and Practice, 7 Fla. CoASTAL L. Rev. 95 (2005); David B. Wexler, Therapeutic Jurisprudence and the Rehabilitative Role of the Criminal Defense Lawyer, 17 ST. Thomas L. Rev. 743 (2005) (Wexler, Rehabilitative Role); David B. Wexler, Some Reflections on Therapeutic Jurisprudence and the Practice of Criminal Law, 38 CriM. L. Bull. 205 (2002).

2009 WL 2929808 (E.D. Pa. 2009).

Id. at $* 2$.

Id.

See e.g., Arie Freiberg, Non-Adversarial Approaches to Criminal Justice, 16 J. JuD'L Admin. 205 (2007); Wexler, Rehabilitative Role, supra note 83 , at 745 . On the need for criminal defense 
lawyers to have "TJ conversations" with their clients in insanity and incompetency cases, see Michael L. Perlin, "Too Stubborn To Ever Be Governed By Enforced Insanity": Some Therapeutic Jurisprudence Dilemmas in the Representation of Criminal Defendants in Incompetency and Insanity Cases, 33 INT'L J. L. \& PSYCHIATRY 475 (2010).

See supra note 28.

Harold Bursztajn, a forensic psychiatrist with whom I have coauthored a book largely from a TJ perspective (see Psychiatric ETHICs, supra note 28), has approached other related topics from this vantage point as well. See e.g., Harold Bursztajn et al, Medical and Judicial Perceptions of the Risks Associated with use of Antipsychotic Medication, 19 Bull. AM. ACAD. PsychiATRY \& L. 271 (1991); Harold Bursztajn et al., Beyond the Black Letter of the Law: An Empirical Study of a Judge's Decision-Making Process in Civil Commitment Hearings, 25 Bull. Am. ACAD. Psychlatry \& L. 79 (1997) (both comparing and contrasting judicial and psychiatric responses to issues in the commitment and involuntary treatment processes).

Wexler, Rehabilitative Role, supra note 83, at 746.

Philip D. Gould \& Patricia H. Murrell, Therapeutic Jurisprudence and Cognitive Complexity: An Overview, 29 Fordham Urb. L.J. 2117,2120 (2002).

See e.g, Jonas R. Rappeport, Belegaled: Mental Health and the Law in the United States, 1986, 32 CAN. J. PsyChIATRY 719, 725 (1987).

See Wexler, supra note 23 , at 766 n. 29.

Consideration of these tensions is nothing new. See e.g., Benjamin Karpman, On Reducing Tensions and Bridging Gaps Between Psychiatry and the Law, 48 J. CRIM. L., CRIMINOL. \& POL..SCI. 164, 171-72 (1957). See, on the issue of TJ's redemptive power in general, Michael L. Perlin et al., Therapeutic Jurisprudence and the Civil Rights of Institutionalized Mentally Disabled Persons: Hopeless Oxymoron or Path to Redemption, 1 PsYCH. PUB. Pol. \& L. 80 (1995).

Minimizing HARM, supra note 2.

Id. at xxix. 
See http://www.bobdylan.com/songs/i-and-i (last accessed, January 24,2012 ). I have only been fortunate enough to have seen $I$ and I once in performance (see http://boblinks.com/120897s.html). It was the greatest single live performance of a single song I have seen Dylan sing since, at least, the mid-1960s.

See Paul Williams, Bob Dylan, Performing Artist: 1974-1986 (1994 ed.), at 239-240. The chorus includes the line "no man sees my face and lives, paraphrasing Exodus 33:20 (Gd's response to Moses when Moses asks Gd to show him his glory).

See David B. Wexler, Therapeutic Jurisprudence, in Justice AS A Basic Human Need 64-65 (Anthony J.W. Taylor ed., 2006).

Bruce J. Winick, The Jurisprudence of Therapeutic Jurisprudence, 3 Psychol., Pub. Pol'y \& L. 184, 185 (1997).

Debra L. Muller-Harris, Animal Violence Court: A Therapeutic Jurisprudence-Based Problem-Solving Court for the Adjudication of Animal Cruelty Cases Involving Juvenile Offenders and Animal Hoarders, 17 Animal L. 313, 316 (2011).

Deborah Chase \& Peggy Fulton Hora, The Best Seat in the House: The Court Assignment and Judicial Satisfaction, 47 FAM. CT. REv. 209, 210 (2009).

Toki, supra note 31, at 69 .

Perlin, Ghettoization, supra note 2, at 876. See also, Perlin et al., supra note 94; Michael L. Perlin \& John Douard, "Equality, I Spoke That Word/As If a Wedding Vow": Mental Disability Law and How We Treat Marginalized Persons, 53 N.Y.L. Sch. L. REV. 9, 14 (2008-09): "I believe that the use of TJ-as a... mechanism for advancing social justice [-] is a way (perhaps the only way) to redeem the law for persons who have been marginalized" (quoting Michael L. Perlin, "Equality, I Spoke That Word/As If a Wedding Vow": Therapeutic Jurisprudence and Social Justice (Mar. 2007) (unpublished paper, presented at conference at John Jay College of Criminal Justice, New York) (on file with author); MichaEL L. Perlin, The Hidden Prejudice: Mental Disability on Trial 301 (2000) ("TJ carries with it the potential to offer redemption for all mental disability law."). 